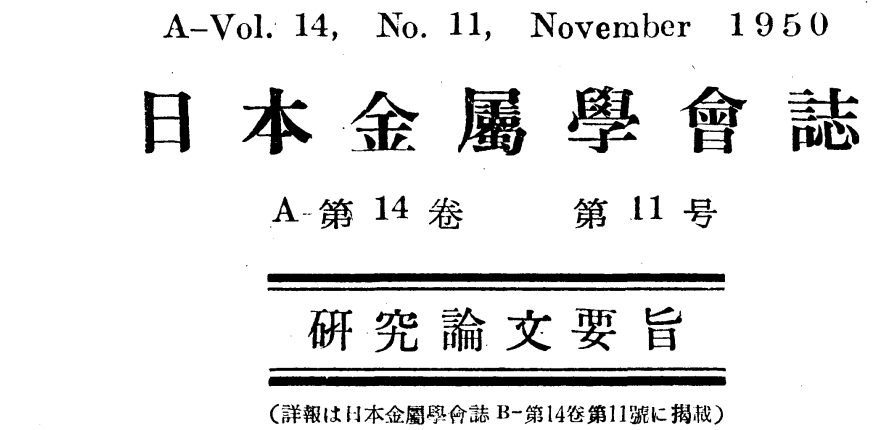

熔融鉄合金のガス吸収（第 4 報）二元合金の二原子分子 ガス吸収に関する理論と笑験

東北大学選鉱製鍊研究所斎藤恒三

既報 [本誌, B-14 (1950)，No. 4，1] の垁驗結果及び理論 によると， $\Lambda B$ 二元合金が $a$ ーガスを吸收した場合，該合金 結晶格子間の空所に位置与る溶解 $\boldsymbol{a}$-原子の配 置は一般に は必ずしも統計的無秩序分布ではない. 郎ち $\Lambda, B, \alpha$ 原子 の配置狀洗は $A$-原子と $\alpha$-原子間の相互.エネルギー $\Psi_{A \alpha}$ 及 び $B, \alpha$-原子間のそれ $\Psi_{B \alpha}$ によつて支配されるのであつ $\tau$ ，例えば $\mathrm{Cr}-\mathrm{N}$ 原子間の $\Psi_{C r N}$ は $\mathrm{Fe}-\mathrm{N}$ 原子間の $\Psi_{F e N}$ よりかなり大であるから Fe-Cr 合金に揖いては溶解 $\mathrm{N}$ 原 子の周りには $\mathrm{Cr}$-原子がその本均濃度以上に配置するので ある. 本報告はからる事笑を根拠にして導入した統計熱力 学的理論を実驗結果と比較考察したものでこれを要約する と次の通りである.

（i）純金属 $\Lambda$ (Poor $\Lambda$ bsorber) の铇和吸收量 $y_{0}$ は次式 で表わせる[本誌，B-14 (1950), No. 1，28].

$$
y_{0}=\lambda_{\alpha}^{g} J_{\alpha} e^{-\frac{\Psi_{A \alpha}+\chi_{a l} / 2}{k T}}
$$

(ii) 二元合金 AB (Poor Absorber) の吸收量yは

$$
y \div y_{0}\left(1-x+\div \frac{x}{k}\right)^{6}
$$

こ」にK $K=\exp \left(-\Delta \Psi_{\alpha} / z^{\prime} k T\right) ; \Delta \Psi_{\alpha} \equiv \Psi_{A \alpha}-\Psi_{B \alpha}$ であ
つて，Aに Bを $x$ モル分率合金させることによる吸收量 $y$ の变化は合金組成 $x$ 及矿 $\Delta \Psi_{\alpha}$ により決定される。

本式は熔融鉄合金と混合氣相との平衡に関する竹內の理 論（昭和 24 年名古屋大会）の特別解に相当寸る.

（iii）純金属B（（ｏod Absorber）においては溶解ガス 原子同志の相互作用 $\Psi_{\alpha \alpha}$ を考㱏に入れ立論すると，その飽 和吸收量 $y$ は

$$
\frac{y}{1-y}=\lambda_{\alpha}^{g} J_{\alpha} e^{-\frac{\Psi_{B \alpha}+\chi_{a} / 2+\Psi_{\alpha \alpha} y_{\ldots}}{k T}}
$$

である. 郎ち(i) 式と比較すると右辺に $\exp \left(-\Psi_{\alpha \alpha y} / k T\right)$. 項が余計に附加された式になる.

(iv) 二元合金 $A B($ (kood Absorber) については

$$
\begin{gathered}
\frac{y}{1-y}=\lambda_{\alpha}^{a} J_{\alpha} e^{-\frac{\Psi_{B \alpha}+\chi_{a} / 2}{k T}} e^{-\frac{\Psi_{\alpha \alpha}}{k} T^{\prime}-\frac{y}{x}} \\
\left(\frac{x-y}{1-y}\right)^{6} \text { である. }
\end{gathered}
$$

以上の諸吸收式は著者の実驗結果及び從來のものをかな り満足に解明するものであることを示した.

Geiger-Müller 計数管による金淈及び合金の諸性質の研究（第 2 報）

金蜀中への'Thの拡散

（昭和 25 年 4 月本会東京大會比被表）

富山大学工学部 森 永 卓一次城大学工学部 塩 田 信 雄

著者等は既に第 1 報で報告したような裝置を使用して， 固体 $\mathrm{Al}$ 不び $\mathrm{Fe}$, 愹体 $\mathrm{Al}$ 等への $\mathrm{Th}$ の相互执散現象を調 べて見た. 純粹の $\mathrm{Th}$ を得るために, $\mathrm{ThO}_{2}$ を炭素電極に 充填して直流電弧で $2000^{\circ}$ 上上の高溫に数分間保持し，種 々の崩㐭生成物を蒸発除去した. Th の放射能力゙約 1 週間 後から一定することを予備実驗から認めたから，少くとも 前述の期間を経過してから湘定を開始した. 実驗方法を略 記すると次のようである。純粹な Thを先ず $\mathrm{Th}\left(\mathrm{NO}_{3}\right)_{4}$ K して被拡散試料面に塗布する。このとき $\mathrm{Al}$ は $\mathrm{HNO}_{\mathrm{s}}$ に腐
蝕されないが, $\mathrm{Fe}$ の方は鹰蝕されて厚さが变化して央驗の 正確を期し難いららみがある。A1 対する执散溫度は固 体 A 西とを 500 600 の範囲, 熔体 11 にいては 750〜 $800^{\circ}$ の範囲にとる. Fe については 700 910 の範囲とし, 拡散後の拡散恒数は從來の式から容易に求められる. 固, 熔両狀態の $\mathrm{Al}$ 中への拡散恒数は, この厼驗溫度範囲では 余り著しい相違は認められないが，拡散速度は決して速く ない. 多結晶体と單結晶体に対する Th の拡散能は相当ち がい前者に対する拡散は容易で，後者に対する抎散は困難 
である．即ち粒界拡散の方が，粒內拡散より容易に行わわ ることが制る・熔体A1に対する拡散は主として拡散溫度 に支配され，溫度の高いほど抬散は旺んでこの点は異論は ない, $\mathrm{Fe}$ 中への $\mathrm{Th}$ の拡散は他の金属の場合の Cementa tion と全く同樣であるが，相違する点は $\mathrm{Fe}$ への Th の拡 散がある程度に達すると脆い化合物を生成し劋離し易くな る. この生成化合物の分子式は正確には決定していない が, 多分 $\mathrm{Fe}_{3} \mathrm{Th}$ に相当寸るものと考えている. それで剥離
層の厚さと拡散溫度との関係を求めると $\Lambda_{9}$ 变態で飛躍し さらに拡散恒数とも比例的な関係が存在する. 要するに放 射能をるつ金属元素を $\mathrm{A} 1$ 及び Fe に拡散せしめて，濃度と Th の計数值の間に比例的関係が成立することから，接触面 に抢忛るTh の濃度と接触面からの任意の距離に扔ける濃 度に，そのときの記錄值を代入して执散恒数が求められる ことを実驗的に提示したわけである。

\section{繰返し据りによる鋼の材質の変化について (昭和24年11月本會名古屋大會に發表)}

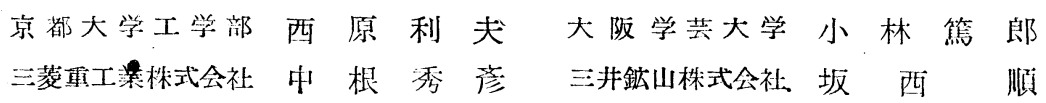

金属の疲勞現薙を理論的に取扱い，或いは機械設計に 取入れるためには，疲勞に件了材質の変化を正確に诚をこ とが必要であるが，本研究は，燒鈍鋼に繰返し据りを與え， 破壞に至るまでの各段階に招ける材質の変化を靜㹉り試驗 により检討したものである.材料は $0.22 \%$ 炭素鋼で, $875^{\circ}$, $2 \mathrm{hr}$ 燒鈍の後, 本行部径 $14 \mathrm{~mm}$ に旋盤加工し, 000 番ペーパ 一で仕上げた. 繰返し摸り試驗機は西原式で每分 2700 回 轉であり，靜㨝り試驗機は松村式を使い降伏点の終りまで は試驗片本行部に籍をつけて捻り角を測り以後はチャック 間の㨝わ角を読取つた。怣驗の結果, 㨝り耐久限度は 13.5 $\mathrm{kg} / \mathrm{mm}^{2}$ と決定し，また降伏点は $\gamma=0.3 \%$ ，と指定した。

据り称呼應力 $\tau=17 \mathrm{~kg} / \mathrm{mm}^{2}$ の場合には 5 段階に亘つて
㨝りモーメント対㨝れ角線図を求めたが，処女材の場合に 儑著な降伏点踊り場は $N=5.10^{4}$ 位から不明膫になり，比 例限は下り，降伏点は上界する。このグループに対する破 断回数は $N=10^{6}$ であるが抗㨝力及び全㨝れ角は隇少し， 材料の脆化は明らかである。

次に㨝り倠力 $14.5 \mathrm{~kg} / \mathrm{mm}^{2}$ に対しても6段階にわたつ てその機栰的性質を調べたが大体に招いて前と同じ傾向を 示した.

耐久限度の直下と思われる應力 $13.0 \mathrm{~kg} / \mathrm{mm}^{2}$ を加之な 試驗片でる $N=1.5 \times 10^{7}$ になると踊り場が明瞭となるな ど材啠の変化が認められた。

\section{金屬レブリカの研究 (第 1 報) 銓, 特殊銅, 鋳鉄のレプリカ法について}

\section{東京都立大学工学部 田辺㢃美}

本研究は腐蝕を完了せる金属面にこれより電氣化学的に 貫なる金属の塩類溶液またはその塩酸々性溶液を金属面に 滴下鍍金せしめ，これをセルロイド板に醋酸アミールを使 用して剩離しレプリカを检鏡せんとするものである。滴下 する際は溶夜に氣泡を作らぬこと及び金属面を速かに溶液 で覆うことに注意を要し溶液を振動せしむることが必要で ある.銅の被膜が完全に出來る時間は液溫，材質，組織に より一定せず約 30 秒乃至 1 分30秒である.

レプリカのために用いた材料は炭素鍽，鏟鉄，特殊鍽に して塩化銅アンモン，塩化第二銅及びこれ等の塩酸々性溶 液をレプリカ溶液として使用した。

次にこれ等溶液の置掺についてはフェライトとセメンタ イトの置換を比較するとフェライトの方が置換し易く，從 つて炭素含有量が增加すると置換を促進せしむるために銅 溶夜の\%を增加せしをる．この際フェライトの多く存在す る組織においてはフェライトが均一に置換されず区画が生 ずるため醏酸を順次加えると不均一狀態は次第に消失し一 定の量で最良の狀態となり再び不均一となる．この最良の 狀熊は炭素含有量の增加と共に㙁酸量は減少する方向に移 動し大約共析点で零となる。この塩酸の作用は $\mathrm{H}$ の特性
により置換を均一に促進せしむるものと考えられる.

次にマルテンサイト，トルースタイイト，ソルバイトにつ いては標淮組織のものと大体同一のレプリカ溶液にてレプ

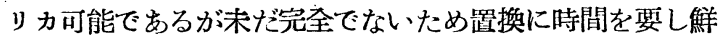
明なレプリカが得られていないので詳細を检討中である。

夯に鑄鉄についてはダラファイトは置換せざるため化合 炭素の量によりレプリカ溶夜の組成は決定された。また可 鍜鑄鉄襱鈍前後の組織は組織上からそのレプリカ溶液の組 成は変つて來た・次に特殊鋼についは炭化物，複炭化物の あるものについて置換が困難でレプリカに括いて檢鏡する と中心が黑く周囲が白く現われたが組織としては明膫に織 別し得た。また高満俺鋼の場合はオーステナイトであるた め純鉄の場合と同樣に均一を計るため塩酸量は多くなり銅 溶液の濃度が高き場合には炭化物は置換され低ければ置換 されず黑く表われたままた高ニッケル高クロム鋼には礁用 出來なかつた．從つて炭素鋼，特殊銅，鑄鋼，鑄鉄，可鍛 鑄鉄, 高級鑄鉄, 特殊銡鉄に招いて $5 \%$ ピクリン酸アルコ 一ル溶液 $5 \%$ 硝酸アルコール溶液にて庥玲を行い得る材料 についてはレプリカが可能であることを確めた. 
N1 及びその合金の諸性貿に廷ぼす含有瓦斯の影響（第4 報)

\begin{tabular}{|c|c|c|c|}
\hline 茨城大学工学部 & 岩村 率郎 & 塩田 信雄 & 小野崎 長 英 \\
\hline 日立製作所鋝鋼課 & 丹 啮 平 & 飯臭 㴋三 & \\
\hline
\end{tabular}

ダイカスト用合金の鑄引伋び多孔性の問題は合金の種類 或いは鑄造操作によつてもかなり異つてくるが，それ以外 に合金の瓦斯吸收と吸收された瓦斯が凝固の場合，合金中 にどの程度残留せられ得るかによつて顯著な影響を及代さ れる. 著者等は前報において熔解時の流動性自体にも水素

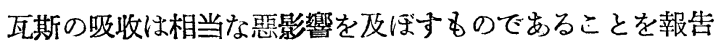
したが今回はがイカスト鑄造條件中，鎬造機の注加圧力を $40 \mathrm{~kg} / \mathrm{cm}^{2}$ 及び湯口の厚みを $1 \mathrm{~mm}$ 一定として, 鋀造溫度及 び金型の溫度を変化せしめた場合の $\Lambda \mathrm{I}$ 及び Lautal 2 種類 の試料についてその抗張力, 衝摮, 耐蝕性並びに燒鈍狀 態への含有瓦斯の影響について檢討を加えた，即ち試料を $\mathrm{ZnCl}$. によつて可及的に眖瓦斯操作を施した場合 (a) 金型 鑄造直前に $15 \mathrm{sec} の$ 水蒸氣欣込を行つた場合 (b) 及び鎄
造機上型の溫度を水冷操作によつて冷却した場合 (c) の垁 驗結果である、Al試料について例を探れば $700^{\circ}$ 鑄迈みの 場合の抗張力は (a) : $19 \mathrm{~kg} / \mathrm{mm}^{2}$, (b) : $16.5 \mathrm{~kg} / \mathrm{mm}^{2}$, (c) : $27 \mathrm{~kg} / \mathrm{mm}^{2}$, 衝擎值は (a) $: 3.1 \mathrm{~kg} \cdot \mathrm{m} / \mathrm{cm}^{2},($ b $): 3 \mathrm{~kg} \cdot \mathrm{m} /$ $\mathrm{cm}^{2}$, (c) $: 3.4 \mathrm{~kg} \cdot \mathrm{m} / \mathrm{cm}^{2}$ であり耐蝕性は (b) (a) 及び (c) の順に良好になるのが認められた. 高溫燒鈍しの影響は Alに执いては顯著に認められないが, Lautal では $520^{\circ} 2$ $\mathrm{hr}$ の処理によつて暮肌の発生狀況に可成りの羑違が認め られた.これを要するに冷却効果を利用して鑄巢, 引巢を 可及的に除去せしめるためには $\Lambda 1$ 或いは Lautal によつ てその最邀溫度 $700^{\circ}$ 或いは $730^{\circ}$ 近辺を選んで銡迈々を行 うべきである。

$$
\begin{gathered}
\text { アミニウム文びその合金の真空放溉脱瓦斯法に関古石研究(第 } 1 \text { 報) } \\
\mathrm{Al} \text { 基二元合金の含有瓦斯量 测定 }
\end{gathered}
$$

(诏和 24 年 4 月本會東京大會儿。發琵)

$$
\text { 茨城大学工学部 岩 村. 溗 郎 鈴 木正敏 }
$$

$\mathrm{Al}$ 及びその合金中に含有される瓦斯 (主に水素)を偩空 愹融脫瓦斯するとその放出量は通常 1 2 ce/ 1 cog d metal であるが，著者の 1 人は前に [岩村, 本誌, 7(1943)，508] この愹颜試料を一方の電極として傎空放電を與えることに より 10〜20 cc/100 g·metal の放出量を得た. 本報告に㧤 いてはそれを更に系統的㳊調べるべく $\Lambda 1$ に $\mathrm{Mg}, \mathrm{Zn}$ 及び Mnをそ机ぞれ 1 5\% 添加せる二元合金に対し，本脫瓦斯 沠を適用し，源加元素の種類，量，脫瓦斯溫度等と放出瓦 斯量との間の関係を調べた.

垁驗泆としては橫型電氣俎中に磁製管を入れ，その中試 料を乘せを磁製隹ートを入れて，磁製管內を拝空にし，そ の圧力を湘定して後電氣伢で加熱し, 所要溫度に到達して 後放電を開始する．放電裝置としては磁製管の両端よりタ ングステン棒を差込んであり，その一方は試料に接着せし めてあり，試料と他方のダングステン棒との間で黄空放電 せしめる如くなつている. 試料処理溫度は熔融点以下゙の $600^{\circ}$ そそれ以上の $700^{\circ}$ 及び $800^{\circ}$ の 3 種類をとり, 放電條 件は A.C. $5000 \mathrm{~V}$, 数 $m \Lambda$ の程度で㟧る. さて時間の進行 そ共に含有瓦斯は放出せられ，從つて队部の生力は管加し て行くが，その堆加の割合は時間と共に減退する.かくて
內部が平衡狀態に到達したときに放電を中止し，全体を冷 却後, 內部の圧力が処理前と比べてどれほど增加したかを 比較し，その羑から放出瓦斯量を計算する.な扔試料とし ては水素瓦斯を十分に飽和せしむるため，金型鑄造前に30 秒ぼど熔湯中に水蒸氣を吹迈んだものと、しからざるもの との 2 種類を用いた・上記の如き垁驗の結果得られた所は 大体次の通りである。

（1.)これ等二元合金の舍有瓦斯量は純 $\mathrm{AI}$ の場合に比し 何れも大であり，その暼加割合は $\mathrm{Mg}$ が最も大で $\mathrm{Mn}$ がこ れに次ざ Zn の場合が最も小という結果を示した.これ等 のらち $\mathrm{Mg}$ 涯加による含有量の塯加は特に著しく大であ り,純 $\mathrm{Al} 800^{\circ}$ で処理した場合その放出瓦斯量は 10一20 cc/100g-metalであるが，Mg 5\% 添加の場合同一條件下 で $30 \mathrm{cc} / 100 \mathrm{~g} \cdot \mathrm{metal}$ 以上もの瓦斯を放出するようになる. (2) 第二元素の量が㗍加するにつれて，その放出瓦斯量も 增加する. (3) 処理温度の低い:ど放出瓦斯量は少く, 温 度の上梨と共に墳加する. 熔融点以下で本法により処理し ても他の方法によるものと大善無い結果を生ずるが，これ を熔融狀態の試料に対して適用するときは，その放出瓦斯 量を著しく增大せしめ得る.

\section{アルミニリム及びその合金の真空放電脱瓦斯法に関する研究(第 2 報) \\ 種々の脱瓦斯処理在施せる $\mathrm{Al}$ の格子常数变化精密测定について \\ （昭和24年11月本会名古能大會以發垡）}

茨城大学工学部 岩村茂郎千早正鈴木正敏

ヘ】鑄物のピンホール除去のために現在有効とされてい る榙種の処理法を施した試料に対し，その格子常数を精泌
測定法によつて求めた. 即ち $99 . \% \%$ の純 $\mathrm{A} I$ に再熔融法,

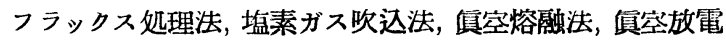


泆の各種処理を行つて見たのである.これ等試料を背面反 射法によつてそのデバイ写真をとり，次で精密計算法によ りその格子常数を求めた。得られた結果は大要次の通りで ある。

(1)一般に脫瓦斯処理を行弓とその格子常数は以前より も收縮を示す.（2）頁室裝置を用いずに大氣圧下で行う処 理法の內では愹融金属中に塩素ガスを吹込む方法が最も有 协であることが判つた.（3）偩宾熔融法は通常合有瓦斯の 定量に用いられる方法であるだけに以上の方法中では最も 有効と思われ，その格子常数收縮も相当大である. (4) と
ころが傎空放電法によれば一層多量の瓦斯放出が認められ ると同時に，その格子常数收縮も最も大であり，特に試料 を陽極にした場合，郎ち試料（熔融狀態）が電子衝摮を受 けた場合にその効果が著しいことを見出した。（5）な牤㑯 空放電法を用いる洔は試料が陽極か陰極かに拘らず一種の 纎維組織ようのものが出現することをX線写俱より発見し た.その組織の詳細は目下な挌不明であるが，何れにせよ か、る現象は單なる㑯室熔解等では起らず，これに放電を 與えた時にのみ起るものだあることは確認した。

\section{酸化鉄による瓦斯の脱硫に関する基礎的研究}

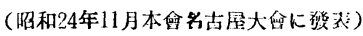

$$
\text { 名古屋大学工学部 佐 野 幸吉 村頼 照 明 }
$$

冶金工業において使用せられる燃藮用瓦斯中に硫黄含有 量が高くなると当然製品の含硫黄量を堁大寸るのでこれ等 の瓦斯は予め脫硫することになつている.この目的には從 來酸化鉄が色々の狀態て脫硫㓮として使用せられているが 酸化鉄の眖硫力はこれを焙燒する溫度の高低によつて著し い影響を受ける。

例えば $200^{\circ}$ で焙燒した酸化鉄は相当に脫硫能を有つて いてもこれを一度 $1000^{\circ}$ に焙侽すればその能力は完全に無

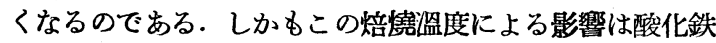
粒子の分散狀態によつても变化する. 郎ち $\mathrm{Al}_{2} \mathrm{O}_{3:}, \mathrm{SiO}_{2}$, $\mathrm{Cr}_{2} \mathrm{O}_{3}$ 等を添加して分散度を增大寸れば相当高溫度まで焙

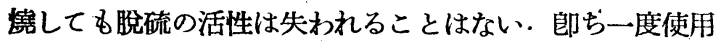
した脫硫郕を焙燒して再生する目的には便利である.本研 究においては酸化鉄を主とする脫硫剤について組成製造條 件及び熱処理と眖硫能及び再生性との関係を究明した．契
驗結果を要約すると次の如くである.

（1）含水酸化鉄の脫水溫度と脫水率は脫水溫度が高い: ど脫水率は高く，また $\mathrm{\Lambda}_{2} \mathrm{O}_{3}$ 源加量が垤大寸ればするほど $\mathrm{Al}_{2} \mathrm{O}_{3}$ の分子量が $\mathrm{Fe}_{2} \mathrm{O}_{3}$ に比較して小さいために脫水率は 高い（2）含水酸化鉄の脫水溫度と瓦斯吸收率との関係は $\mathrm{H}_{2} \mathrm{~S}, \mathrm{SO}_{2}$ 等の瓦斯の種類に上り稍 3 傾向は異るが $\mathrm{H}_{2} \mathrm{~S}$ 瓦 斯の場合に招い,ては 400 600 附近に拁いて四收率の最大 を示しまた $\mathrm{SO}_{2}$ では $200^{\circ}$ に掠いて吸收率が高い，しかも $\mathrm{Al}_{2} \mathrm{O}_{3}$ の涯加量が增大寸れば瓦斯の吸收率は高く，かつ最 初の脫水溫度の影響は無視し得る程度に低くなる。(3) 瓦 斯を吸收した眖水酸化鉄の焙燒溫度と再生率との関係につ いては焙燒溫度が $600^{\circ}$ に扔いて $100 \%$ の再生率を示し, し かも $\mathrm{Al}_{2} \mathrm{O}_{3}$ の多い試料では焙然溫度が同じでも再生率は 高い。

\section{鉄 銹 の発生機 構とその防止}

\section{大阪大学工学部冶金学教室 多賀谷正義 伊 佐 重 輝}

近年輸出向機諓及びその部品特よび紡績用針並びに針布 線の防銹が重要な問題となつて來たので，0.06〜0.70\% 炭 素鋼，1 2\% Cr 鋼について大氣中での銹の発生機構を観 察しあわせて防銹対策を研究し，また針布線の表面流出電 流を測定して外國製と國座針布線の表面狀況を比較した。 その結果の大要は次の如くである.

（1）磨いた鉄面に発生する銹はその形狀が点狀銹, 粒狀 銹, 系狀銹, 塊狀銹に大別し得る.肉眼で認め得る銹は塊 狀銹の成長したものである.（2）塊狀銹は鉄面への水滴の 凝結筒所から成長寸るるのと，非金属介在物から成長寸る ものとがある. 後者の成長速度は前者に比し遥かに遅い. 前者では酸素濃淡電池の作用により水滴の中心部が電氣化 学的に腐蝕せられ, その後水滴の外部に銹力゙樹枝狀に発涬 する.これが鉄銹の決定的な素因となる. 後者はとれに水 分が四藏せられて銹が進行するよらに見られる.な澍枝 狀に生じた塊狀銹は吸登性で盆 く 発達し, またその周辺に 水滴を凝結する原因となる. (3) 炭素鋼ではパーライト地 より発銹し易く從つて炭素量の多いものほど発銹量は大で ある、1〜2\% Cr が入ると発銹量は減ずる（4）種々の熱
処理を施した炭素鋼では $800^{\circ}$ から水㷪入し $450^{\circ}$ で燒戻し たものが発銹量が最も少い（5）鉄面へ附着した種々の物 睤の粉末からの発銹は, 㙁化アンモン, 食塩, 塩化マグネ シウム, 艺砧, 酸化第二鉄, 鉄粉, 理砂, 燒石育、アルミ ナ，石灰と順次発銹は少くなり， C, Si, $\mathrm{Pb}, \mathrm{Zn}, \mathrm{Cu}, \mathrm{W}$, Mo等の金属粉末よりは殆んど発銹しない. (6) 鉄面の仕 上程度の影響については，No.1 ペーパー仕上げのものが 見掛けの銹は最も少心，電解研碳したものは後の洗條が充 分でないと却つて布研磨より恶く, 電解洗條したものは, 除極処理の方が陽極処理より不良である・（7）乾燥空氣中 に長時問保存するか，重クロム酸加里または燐酸りーダの 溶液中に長時間浸清して，表面に安定な酸化膜を生ぜしめ ると防銹効果は大となる. (8) 防銹油としてはワセッンが 最良で全く銹を生ぜず光沢も失わない：また動物性油の方 が植物性油より大体防銹効果は大である.（9）表面を脫炭 すれば (3) の原因から防銹勃果を㙁す．（10）外國製針布 線は國產に比し，既に表面に安定な酸化膜を生じているた めに中々銹ないことがオッシログラフで表面流出電流を測 定することによつて制明した。 


\section{メタノールによる銅の腐玲の電子迴折的研究}

\section{東北大学金属材料研究所小川四郎渡辺伀次郎}

メタノールによる銅の應蝕の研究は先に乾氏等が主とし て鹰蝕試驗，化学反應の見地より研究してその機棈を推論 した. その際電子䞤折的研究子若干行つたが笑驗が少く有 力な data とはならなかつたので, 今回われわれは更に詳細 にメタノールによる銅の腐蝕面を電子廻折的に反射法によ つて研究した. 用いた試料片は日本製 $(99.82 \% \mathrm{Cu})$ のもの と米國製 $(99.92 \% \mathrm{Cu})$ のものと 2 種類で，これを盐酸塩化 第二鉄メタノール溶液で数分間腐蝕した後丁寧に洗涤して 試驗メタノール(市販)中に浸漬した・浸清腐蝕面の電子逼 折写傎は一般に迵折環の强度が小でぼやけて括り面間隔の 湘定が困難であつた．測定の結果は 2 種類の銅表面は共に 浸清後数日間は $\mathrm{CuO}$ と $\mathrm{Cu}_{2} \mathrm{O}$ の雨方を生じ,後次第に $\mathrm{Cu}_{2} \mathrm{O}$ は減じて長時間（約 10 日間）の浸清では $\mathrm{CuO}$ のみとな が，米國製のものは若干变化が紳慢である. 應蝕面の肉眼 的観察では制然とした羑異があり，日本製のものが次第に 鉛色になるのに比し米國製のものでは 8 日後でも赤紫色で あつた・次に浸漬の初期よりCuOが形成されるものか否 かを調べるために短時間 (数 10 分乃弪数時間)の浸漬によ つて試驗を行つたところ，銅以外の迴折環は大体CuO だけ でまたは $\mathrm{CuO}+\mathrm{Cu}_{2} \mathrm{O}$ で說明でき， $\mathrm{Cu}_{2} \mathrm{O}$ 單独で說明され るものは得られなかつた．要するに腐蝕生成物は銅の酸化 物であり，しかる浸清直後より $\mathrm{CuO}$ が生成されるといえ る. しかし果して以前に報告されたよらな複雜な過瓘で磨
蝕されるものであるか否かを調べるためにメタノールを段 階的に純化しながら浸清試驗を行つた. 郎ち生石灰及び金 属ナトリウムを使用じて脫水したメタノール中で應蝕試驗 (約 2 週間)を行つた結果, 眖水前のメタノールによる磨蝕 の場合とは著しく異なり銅表面は肉眼的には殆んど变化が 無く, 電子廻折写自では銅の廻折環のほかに弱、酸化物 (CuOで說明出來る)の椢折環が得られた. 從つてメタ) ール中に怙ける銅の腐蝕は殆んどメタノールに含まれてい る水分が原因しているといらことが出きる．この電子趣折 的に检出された少量の酸化物は実驗の途中にメタノール中 に吸收された少量の水分によるものであると考えられる。

從つて銅のメタノールによる腐蝕に対しては以前に考え たよろな機棈を考えなくてもよいのであるが，一方水中に 銅片を長時間浸清してもその表面は著しい変化を受けず25 日後でも決して鉛色等にはならないことを考えると，磨蝕 の機構としてはメタノール中に含まれる水溶性の少量の不 純物によつて著しい銅の酸化が生ずると考えるべきであ り，眖水することによつて不純物はイオンと成り得ず，從 つて酸化も起らないのであろらと考えられる.この水に可 溶な不純物の性質と銅の材質とに関係があることは 2 種類 の銅て腐蝕の程度に格段の美があることから推測される が，それ以上のことは現在の段階では不明である。

\section{塩酸による高 $\mathrm{Cr}$ 鋼の腐玲に対与る抑止剤について}

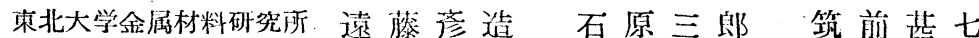

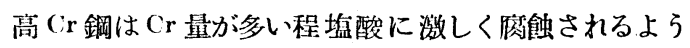
になるがCr は酸化作用によつて最も不働態化し易い金属 であるから高 $\mathrm{Cr}$ 鋼に执いて酸化刘が硫酸の場合と同じよ ろに塩酸に対しても腐蝕抑止郕として作用するか否かを調 べてみた. 酸化剂としては $\mathrm{K}_{2} \mathrm{Cr}_{2} \mathrm{O}_{7}$ を用いこれを2,5; 10， 20 及び $30 \%$ 熄酸に $150 \mathrm{~g} / \mathrm{L}$ (飽和溶液) まで溶解した溶液 中で 14, 20 及び $33 \% \mathrm{Cr}$ 鋼について実驗した. 㙁素イオン は金属の不働態化を最も妨げる作用を有するから予期され るよらに醏酸中では硫酸中よりも不働態化し蜼い. $14 \% \mathrm{Cr}$ 鋼は $2 \%$ 以下, $20 \% \mathrm{Cr}$ 鋼は $5 \%$ 以下, $33 \% \mathrm{Cr}$ 鋼は $10 \%$ 以 下の塩酸に执いての久完全な不働態がえられた。㙁酸中の $\mathrm{K}_{2} \mathrm{Cr}_{2} \mathrm{O}_{7}$ はその酸化作用が高 $\mathrm{Cr}$ 鋼の磨蝕に対して金属酸 化皮膜形成による陽極的抑止剤としてまた復極作用による 陰電的促淮郕として二つの作用を及代すからその十分な添 加は腐蝕の減增または点蝕洞侵蝕の発生を件い甚だ伦險な 隐蝕抑止㨈である.Moを3〜 7\% 合金して固溶体の狀態に 保つことによつて不働態化に必要な $\mathrm{K}_{2} \mathrm{Cr}_{2} \mathrm{O}_{7}$ 量を著しく 減じまた点蝕洞侵蝕の発生を完全に防止することが出來 る. 例えば 10\% 塩酸中で完全な不働態をらるに要する $\mathrm{K}_{2} \mathrm{CrO}_{7}$ の最小量は $33 \% \mathrm{Cr}-3 \% \mathrm{M} \circ$ 鋼は $33 \% \mathrm{Cr}$ 鋼の 1/10000 で十分である.Mo7\% 以上の合金を徐冷した場
合または Mo 10\%以上の合金では水中堯入した場合にも高 $\mathrm{Cr}-\mathrm{Mo}$ 鋼に扔いて不均一組織が現われ不働態化し難くな る. 高 $\mathrm{Cr}$ 鋼の不働態化並びに点蝕洞侵蝕の防止について WはMっのような効力はなかつた. 不働態は溫度に銳敏で 多くの場合 $30 \sim 40^{\circ}$ で活性化された.

高 $\mathrm{Cr}$ 鋼の不働態化に必要な $\mathrm{K}_{2} \mathrm{Cr}_{2} \mathrm{O}_{7}$ の最小量 $C_{0}$, 塩酸 の濃度 $\dot{C} \mathrm{a}$ 及び鎘中の $\mathrm{Cr}$ 量 $x$ (比濃度) との間に簡單な仮 定によつて次の関係式をえた. $C_{0}=0.165 \frac{C_{a}^{2}}{x^{2}}$

また鹰蝕速度 $v$ の $\mathrm{K}_{2} \mathrm{Cr}_{2} \mathrm{O}_{7}$ 量 $C$ による变化は不働態化反 礁か $\mathrm{K}_{2} \mathrm{Cr}_{2} \mathrm{O}_{7}$ の濃度について統計的現鲳であると仮定す れば次式で表わすことが出來る。

$$
v=\frac{K\left(K^{\prime}+C\right)}{\Gamma(n)} \int_{c}^{\infty} e^{-c} c^{m-1} d c \cdots
$$

こっにKは区應速度恒数， $K^{\prime}$ は鋼の組成及び塩酸の濃度 によつて定まる常数, $n$ は不働態の素領域について濃度 $C$ の $\mathrm{i}_{2} \mathrm{Cr}_{2} \mathrm{O}_{7}$ が高 $\mathrm{Cr}$ 鋼の酸化皮膜を形成する反應速度を原 子数で表わした值. この不働態化の不均一さの分散率 $a=$ $K^{\prime \prime} \frac{C_{a}}{x^{2}} \cdots \cdots$ (3) K” は比例常数. (1) は定量的に (2) (3) は定性的に実測値と大体一致した。 
燃焼法による燃料中の全硫黄の定量について

（主として石炭, コークス及び重油中の全硫黄の定量につんて）

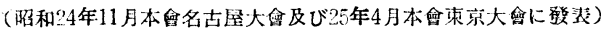

新扶采金属工業株式会社製鋼所桐山 静男

從來より然料中の全硫黄の定量は Eschk 法及び l'arr 式燃燒ボンブ沠による重量法によつているため操作煩雜に して長時間を要しかつ相当の熟練を要した. そこで著者は これを鉄鋼試料と同樣燃燒泆にて定量せんとし種々兴驗の 結果，鉄鋼試料とその含有成分を根本的に異にすることよ り來る二,三の問題を解決し，試料を予熱, 燃勢するいわゆ る二段式燃勢操作により一試料僅かに15分間で迅速簡易に しがも正確にこれら試料中の全硫黄を定量することが出 來，分析能率を著しく向上し得た。

定量裝置：第 1 図に示す如きもので C の石英棒を動かし てボートを予熱低溫部より高溫部にボートを押入れる。

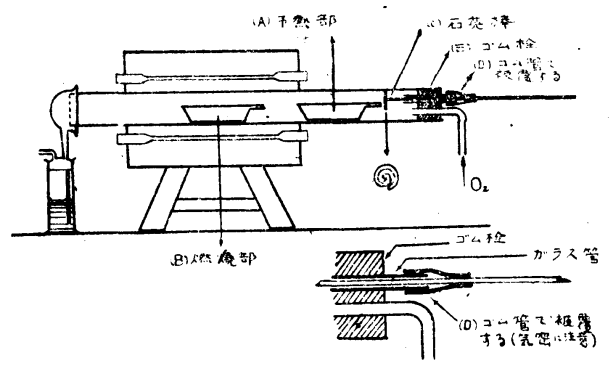

第 1 困

使用試藥液：(1) $\mathrm{H}_{2} \mathrm{O}_{2}$ 吸收液：0.1\%溶液 $20 \mathrm{cc}$ を使用 する. (2) $\mathrm{CuCl}_{2}$ 溶液: $\mathrm{CaCl}_{2} 2 \mathrm{H}_{2} \mathrm{O} 0.0085 \mathrm{~g}$ を水 $1 \mathrm{~L}$ に 溶解し $10 \mathrm{cc}$ を使用する.（3）規定液：N/50 NaOH 溶液

磁氣錄吾機の発達とその磪用二つ 磁氣錄曋は 1898 年W.Poulsen の始唱による至響記錄方泆で，1930 年英 國皇帝が吹込久をしたので実用性が認められ，電子工業 の発展と共に著しく発達した。これは畐響に対㷳する電 流を吹込み用の線輪に流し，線輪內の鉄心を電磁石とな し，この下を通過する磁性体を磁化し吾響を残留磁氣と して磁性体に記錄するという原理に基くものである。そ

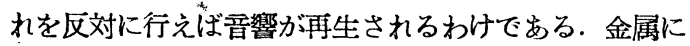
関する部分は被錄晋材料郎ち錄畐合金と線輪用の鉄心て ある・錄昔合金は最初ピアノ線を用いたが Fe-Ni-Co 系 合金が発明され更に不銹鋼や燐銅線の上に $\mathrm{C} 0-\mathrm{Ni}$ 合金 を被覆したものが利用されるようになつた．近年錄曋技 術が著しく進步して合性樹脂のテープに通称ブラック・ オキサイド (Black-Oxide 或いは Red-Oxide) の强磁 性粉末を塗布したものが用いらわ，現在では 2000 回の使 用にも堪えるといわれている，夯に最近日本で笑施され
を使用する。

分析操作 $A$ (石炭、コークス試料): 試料 $0.2 \mathrm{~g}$ (200 mesh) $\mathrm{Ib}_{3} \mathrm{O}_{4} 0.1 \sim 0.2 \mathrm{~g}$ をよく混じてポートに探取し（前方にか ためる) 一方吸收液 $\left(0.1 \% \mathrm{H}_{2} \mathrm{O}_{2} 20 \mathrm{cc}+\mathrm{Cu}_{2}-\mathrm{Cl}_{2} 10 \mathrm{cc}\right) 1$ 箇を硝子キャップに連結し燃燒溫度(中央部) $1100^{\circ}\left(\mathrm{Pb}_{3} \mathrm{O}_{1}\right.$ を使用しなければ $\left.1300^{\circ}\right)$ となしボートを最初予熱部 $\left(550^{\circ}\right.$ 第 1 図 A部）に入れ（予め石英棒の長さと予熱部 $\Lambda$ 点との 距離を測つて特く） $\mathrm{O}_{2} 300 \mathrm{cc} / \mathrm{min}$ で 5 分問通じ次に石英 棒でそのまつボートを燃燒管中央部に押入れ 10 分間 $\mathrm{O}_{2}$ を 流す. $\mathrm{O}_{2}$ を止め吸收器及び硝子キャップを外し吸收液を常 洗通り $\mathrm{N} / 50 \mathrm{NaOH}$ にて滴定し，次にキャップの队側を蒸 溜水にて洗條し同樣に滴定して S\%を求める. 但しコーク ス試料は予熱なしで直ちに $1100^{\circ}\left(\mathrm{P}_{3} \mathrm{O}_{4}\right.$ 不源加の際は $\left.1300^{\circ}\right)$ の高溫部に大れ 15 分間 $\mathrm{O}_{2}$ を通ずる.

滴定 $\mathrm{cc} \times 1 \mathrm{ccS}$ 相当量 $\mathrm{g}-\times 100=\mathrm{S} \%$

分析橾作 B (重油試料)：試料 $0.2 \mathrm{~g}$ をボート先方に探 取し予熱溫度 $450^{\circ}$ (ボート先端溫度) $O_{2} 500 \mathrm{cc} / \min 5$ 分間 (引火完全燃燒) 次に $\Lambda$ と同樣操作をもつて燃燒管高溫部 $1100^{\circ}$ で 10 分間同樣 $\mathrm{O}_{2}$ を通じ以下 $\Lambda$ と同樣に操作する. 但し子熱時硙子キャップより䙹き万一黑煙或いは濃い白煙 を発生しそろな縣念がある時は $\mathrm{O}_{2}$ 流速を少し管:せば消え る. また予熱時約 1 分間以內に引火しない時はボートを前 方に (高溫部) 少しだけ押出して引火させる.

数種の試料につき垁驗の結果甚だ良好なる結果が得られ た.

た例を述べる。

1. 鉄道線路の交通頻繁な踏切には番人が抢つて断遮 機を降すか，または列車が踏切に差しか〉ると警鐘が自 動的に鳴るようにしていたが，これでは完全でないので 警鐘のかわりに回轉型の磁篓錄曋機を用い, “電車が參 ります暫らく持待ち下さい”と再生を繰返し放送するよ らになつた.これは我が國最初の自動発声警報機で東急 目蒲線洗足駅附近の第 4 号踏切にある.

2. 手紙や葉書に書いたことは認拠になつてよいが電 話で話したことは後に残るすのはない，それでこれを錄 豆したい希望が当然起つたが日本では電話施設に他の設 備を直続することが法律上許されないので困つていた。 しかし最近某通信会社で電話器のコイルから漏れている 磁束を利用して法規にふれることなく電話による話を錄 曋できるピッヴアップを作製することに成功した。 